\title{
Stimulation of Gas Emission Processes in Boreholes Using Interval Hydraulic Fracturing in Borehole Local Parts
}

\author{
Vladimir Klishin ${ }^{1,2, *}$, Gleb Opruk ${ }^{1}$, Alexandr Tatsienko ${ }^{2}$ \\ ${ }^{1}$ Federal Research Center for Coal and Coal Chemistry, Siberian Branch of the Russian Academy of \\ Sciences, 650065 Leningradsky Avenue 10, Kemerovo, Russia \\ ${ }^{2}$ Kirov Mine, JSC SUEK-Kuzbass, 652518 Kirsanov Str. 3,Leninsk-Kuznetsky, Russia
}

\begin{abstract}
Due to limited scope of degassing activities and insufficient efficiency of degassing schemes in many methane-rich Russian coal mines there is a gas barrier which prevents miners from achieving high speed at developing mine workings and high working face loads. For that reason there is a strange situation in coal-mining industry when technical capabilities of coal-face operation equipment working on gently sloping coal seams exceed ultimate face load in relation to gas factor several times. The authors prove the efficiency of using coal seam interval hydraulic fracturing for gas drainage stimulation. They consider the established coal seam gas drainage methods. The authors developed the process flowchart for coal seam hydraulic fracturing implementation and suggested using equipment for taking measures aimed at gas drainage stimulation.
\end{abstract}

\section{Introduction}

In-seam gas drainage has become wide spread at high-performance work in coal faces mined in gas-containing coal seams [1-3]. Low efficiency of traditional methods for coal seam gas drainage by means of underground boreholes at high loads on the working faces hinders intensive mining. Besides, the major issues emerge when the operations take place in areas with hazardous geodynamical conditions considering the possibility of rock and coal bump as well as gas outburst occurrence. It is evident that in outburst prone areas in-seam gas drainage stimulation is of paramount importance. According to some estimates, the established degassing equipment being used in Russia helps take out from 20 to $30 \%$ of the released methane total volume [4-7]. Using methods for gas drainage from the surface implies well-known difficulties which have got detailed description in some studies [8-10].

\section{Materials and Methods}

Accumulated experience in the sphere of industrial degassing shows that the existing ways of degassing from underground workings are inefficient. Further efficiency improvement and enhancement of technical and ecological safety during underground mining of coal deposits

\footnotetext{
* Corresponding author: klishinvi@icc.kemsc.ru
} 
with high gas content are connected with the development of special methods and procedures for induced stimulation of gas release from the undischarged coal seams [11-14].

Gas release from the undischarged coal seams can be enhanced by means of improving their collecting properties using interval hydraulic fracturing method (Fig. 1). One of the developed variants was suggested in the previous article [13].

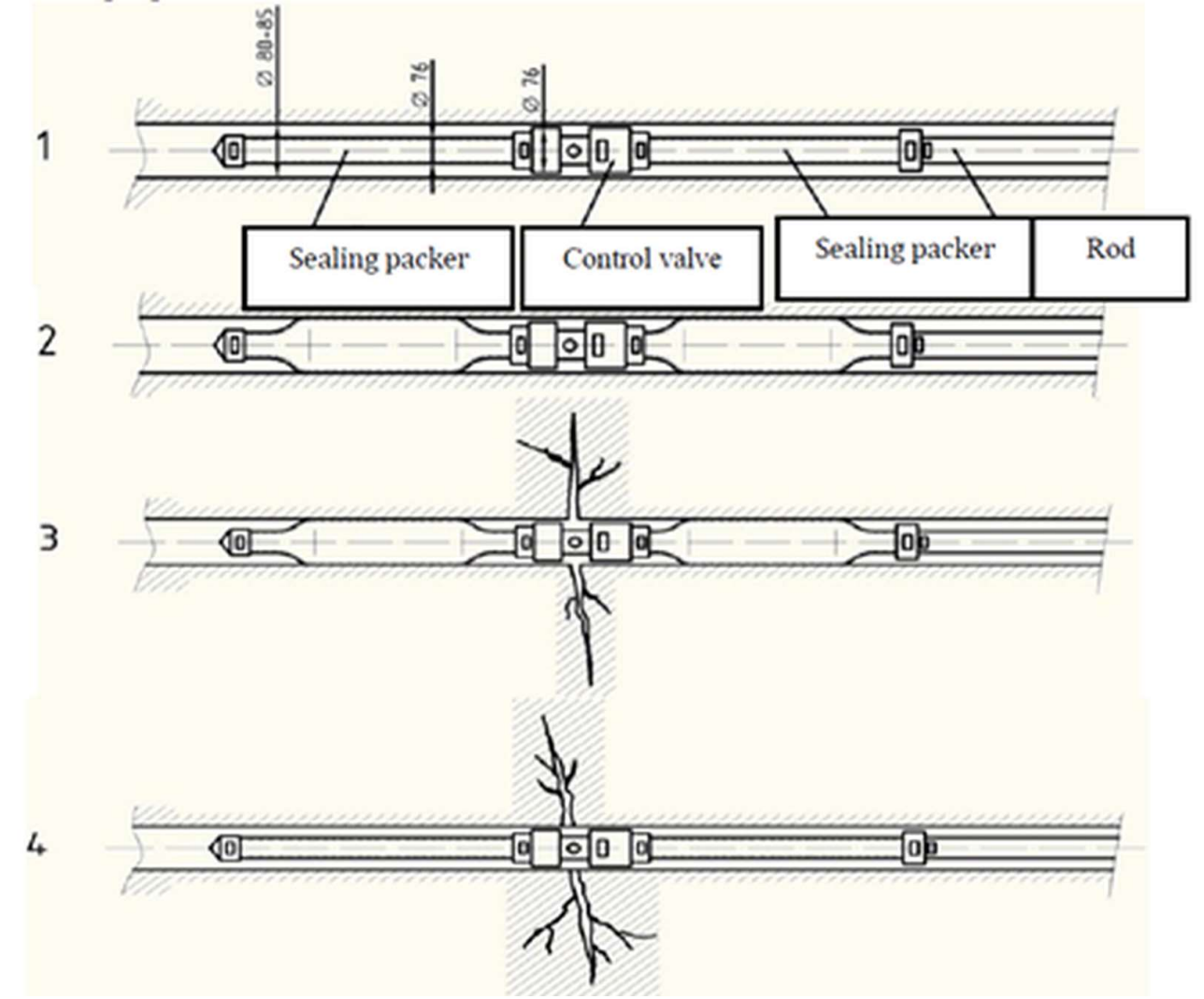

Fig. 1. Implementation of interval hydraulic fracturing method in unmined coal mass: 1 -packer introduction into the borehole; 2 - borehole pack-off; 3 - hydraulic segmentation of the unmined coal mass; 4 - borehole unsealing and change of packer position.

The authors developed procedures and suggested using particular equipment to intensify gas release into methane drainage borehole on the basis of directional interval hydraulic fracturing method [15-18]. The suggested technology can be used according to the following scheme of the directional interval hydraulic fracturing method for stimulation of methane release into methane drainage borehole using such technical means for its implementation as drilling machines, pumping units, and packers (Fig. 2). The authors have chosen drilling machine SBR-400 or SBU-300 for making boreholes and implementing interval hydraulic fracturing $[15,16]$. Both have automatic rod grip without idle speed and fast rod return, which increases performance because it takes less time to perform hydraulic fracturing. 


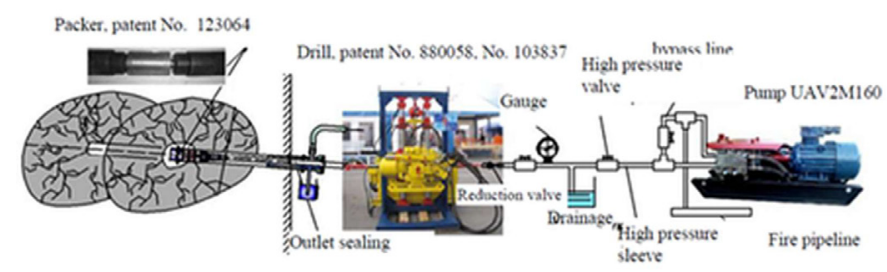

Fig. 2. Stimulation of methane drainage through methane drainage borehole by means of interval hydraulic fracturing.

\section{Results and Discussion}

Special attention is paid to the construction of the valve between the packers. It ensures the supply of the fracturing fluid in any hermetically sealed part of the borehole. Moving the packer along the borehole, one can perform hydraulic fracturing using water or aqueous solutions in certain parts of the coal seam. A balanced packer with a new type of valve makes it possible to increase the reliability of the packing on both sides. To perform interval hydraulic fracturing of coal seam the authors developed a two-side packer (Fig. 3-4). Fracturing equipment includes two elastic expansion sleeves (1) 76 in diameter. Between the sleeves, there is an packer valve (2) which regulates pressure of the fracturing liquid in the hydraulic system of the fracturing equipment. It is used for timely borehole packing in the area between the elastic expansion sleeves and further pressure increase in this area up to the value sufficient for hydraulic fracturing of the coal seam.

Packers have elastic expansion and can enlarge sufficiently in diameter. For that reason, one can easily move the equipment in the initial compressed condition in the borehole and after that make a proper hermetic sealing. However, when the fracturing liquid if supplied into the equipment the elastic elements of the packers enlarge in diameter up to the size when they contact the walls of the borehole. Moreover, as the volume of the elastic elements does not change they shorten axially. As two packers are firmly attached to each other by means of a cylinder-shaped body the place where elastic elements are attached to the sealer bushings is subject to the influence of sufficient extension force which can break that connection. As a result, that reduces the reliability of the equipment operation.

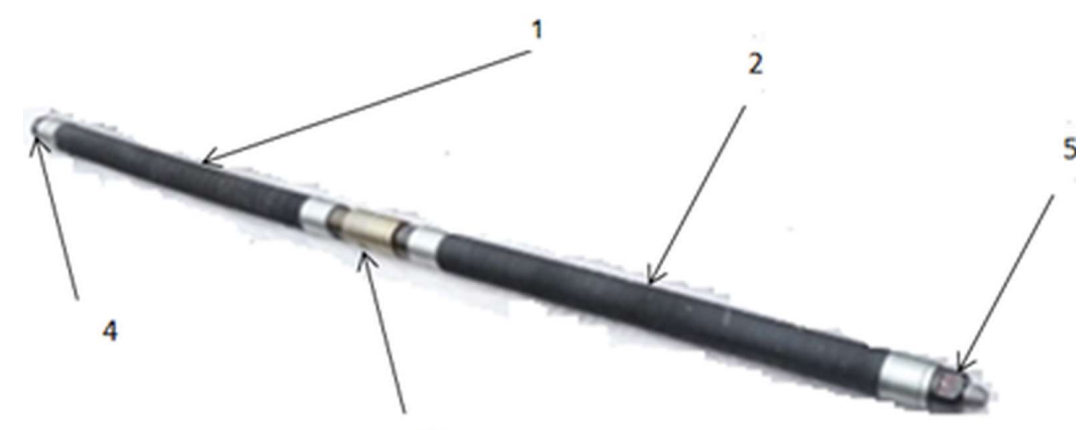

3

Fig. 3. Fracturing equipment and borehole simulator device (construction). 


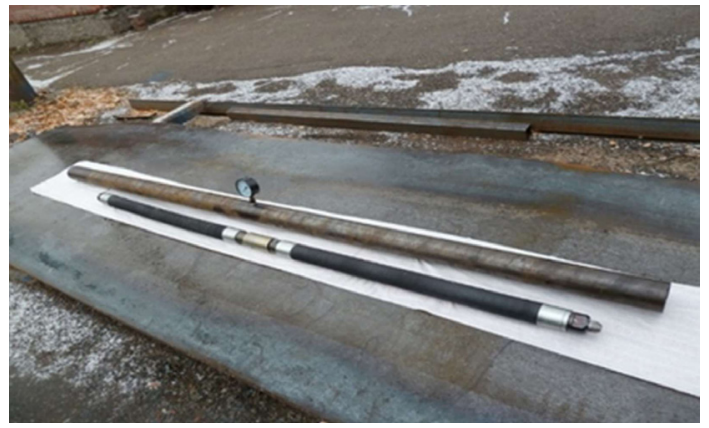

Fig. 4. Fracturing equipment and borehole simulator device: 1, 2 - elastic expansion sleeves, 3 pressure distributor, 4 - locking point, 5-connecting coupling.

It is possible to increase the reliability of the equipment operation if one eliminates the action of the extension forces in the area where elastic elements are connected with the packer bushings by means of including an axial compensator into the design of the equipment for fracturing boreholes in the coal seam. To do that one should install an axial compensator into the equipment for fracturing boreholes in the coal seam between the packers with bushings and a cylinder-shaped body. That improvement enables to increase the reliability of the hydraulic fracturing equipment operation significantly as using an axial compensator eliminates the possibility of the extension force action in the area where elastic elements are connected with the packer bushings.

The equipment for fracturing boreholes in the coal seam (further - equipment) consists of the cylinder-shaped body with holes in its wall so that the fracturing liquid could get through it, packers with bushings and an axial compensator. When the fracturing liquid under pressure is supplied into the equipment through the drill rod the elastic elements of the packers enlarge in diameter and get into contact with borehole walls.

There is a hermetic sealing on the borehole part in the area subject to further fracturing. While the elastic elements of the packers are getting close to borehole walls the packers shorten axially, but this shortening is compensated by the axial compensator work and thus eliminates the emergence of forces which can break the area where elastic elements of the packers are attached to bushings 4 and 5. When the sealing of the area for further hydraulic fracturing is over and the pressure of the fracturing liquid reaches the appropriate value the equipment installed in the cylinder-shaped body with holes in the walls for fracturing liquid inflow into the sealed area starts working. After borehole hydraulic fracturing in the coal seam the pressure of the fracturing liquid is reduced and all elements of the equipment take their initial positions.

\section{Conclusion}

As a result of the performed work the authors suggest developing the basics of the technology which will guarantee triple decrease in the methane drainage borehole drilling footage and at the same time increase the intensity and depth of coal seam degassing at least two times and obtain methane-air mixtures at the end of the process. Achievement of the specified parameters will enable to do the following:

- enhance safety during mining as a result of increase in the depth of coal degassing and decrease in methane outbursts hazard;

- make coal mining safer as a result of decrease in rock bump hazards due to partial relief of the rock mass from the stress by means of hydraulic fractures;

- decrease methane drainage borehole drilling footage; 
- decrease harmful methane emissions into the atmosphere.

\section{References}

1. Guidelines for Coal Mine Degassing (JSC "Scientific Technical Center of Industrial Safety Problems Research", Moscow, 2012)

2. K. N. Trubetskoy, A. D. Ruban, V. S. Zaburdyaev, Journal of Mining Science, 1, 87-89 (2011)

3. A. D. Ruban, V. S. Zaburdyaev, G. S. Zaburdyaev, N. G. Matvienko, Methane in Russian Coal and Ore Mines: Forecast, Extraction and Use (Institute of Comprehensive Exploitation of Mineral Resources Russian Academy of Sciences, Moscow, 2006)

4. N. V. Nozhkin, Preliminary Degassing of Coal Deposits (Nedra, Moscow, 1979)

5. S. V. Slastunov, Preliminary Degassing and Extraction of Methane in Coal Deposits (Moscow State Mining University, Moscow, 1996)

6. Yu. N. Malyshev, Yu. L. Khudin, M. P. Vasilchuk, Issues of Methane-Bearing Coal Seam Extraction in Kuznetsky Coal Field (Academy of Mining Sciences, Moscow, 1997)

7. L. A. Puchkov, S. V. Slastunov, G. M. Present, Perspectives of Industrial Coal Methane Extraction (Moscow State Mining University, Moscow, 2002)

8. P. Sikora, D. Smyslov, O. Pletner, Glukauf, 1, 39-45 (2008)

9. V. B. Artemiev, V. N. Kosterenko, A. P. Sadov, O. V. Taylakov, D.N. Zastrelov, E. A. Utkaev, Extraction and Treatment of Coal Methane (Mining, Moscow, 2016)

10. V. A. Shumilov, S. M. Akselrod, A. V. Shumilov, Geophysical Methods for Borehole Examination during Methane Exploration and Extraction from Coal Seams (Perm State University, Perm, 2014)

11. V. I. Klishin, D. I. Kokoulin, B. Kubanychbek, M. K. Durnin, Ugol, 4, 42-49 (2010)

12. A. D. Ruban, V. S. Zaburdyaev, G. S. Zaburdyaev, Methane in Russian Coal and Ore Mines: Forecast, Extraction and Use (Institute of Comprehensive Exploitation of Mineral Resources RAS, Moscow, 2006)

13. V. I. Klishin, G. Yu. Opruk, A. L. Tatsienko, IOP Conf. Ser.: Earth and Env. Sci., 50, 024556 (2016)

14. R. I. Rodin, M. S. Plaksin, Bulletin of Research Center for Safety in Coal Industry, 1. 42048 (2016)

15. V. I. Klishin, M. V. Kurlenya, Ugol, 10, 34-38 (2011)

16. V. I. Klishin, D.I . Kokoulin, B. Kubanychbek, A. P. Gurtenko, Journal of Mining Science, 4, 50-55 (2010)

17. Patent RF for Invention No 2472941, Method of Coal Seam Hydraulic Fracturing, 2 (2013)

18. Patent RF for Utility Model No 123064, Borehole Equipment for Rock Hydraulic Fracturing, 35 (2012) 